\title{
MIR521-2 Pre-miRNA
}

National Cancer Institute

\section{Source}

National Cancer Institute. MIR521-2 Pre-miRNA. NCI Thesaurus. Code C82842.

MIR521-2 is an oligoribonucleotide that is encoded by the human MIR521-2 gene and has a role in the regulation of gene expression. 